\title{
Biomarkers for Precision Urothelial Carcinoma Diagnosis: Current Approaches and the Application of Single-Cell Technologies
}

\author{
Michelle Hong ${ }^{1}$, George $\mathrm{He}^{2}$, Siting Goh ${ }^{2}$, Alvin Wei Xiang Low ${ }^{3}$, Kae Jack Tay ${ }^{3}$, Tony Kiat Hon Lim ${ }^{2}$, \\ Joe Yeong ${ }^{2,4, * \mathbb{D}}$, Li Yan Khor ${ }^{2, *}$ and Tong Seng Lim ${ }^{1, *}$
}

check for updates

Citation: Hong, M.; He, G.; Goh, S.; Low, A.W.X.; Tay, K.J.; Lim, T.K.H.;

Yeong, J.; Khor, L.Y.; Lim, T.S.

Biomarkers for Precision Urothelial Carcinoma Diagnosis: Current Approaches and the Application of Single-Cell Technologies. Cancers 2021, 13, 260. https://doi.org/ 10.3390/cancers13020260

Received: 8 December 2020 Accepted: 8 January 2021 Published: 12 January 2021

Publisher's Note: MDPI stays neutral with regard to jurisdictional clai$\mathrm{ms}$ in published maps and institutional affiliations.

Copyright: (C) 2021 by the authors. Licensee MDPI, Basel, Switzerland. This article is an open access article distributed under the terms and conditions of the Creative Commons Attribution (CC BY) license (https:// creativecommons.org/licenses/by/ $4.0 /)$.
1 A. Menarini Biomarkers Singapore Pte Ltd., Singapore 117440, Singapore; michelle.hong@mbiomarkers.com

2 Department of Pathology, Singapore General Hospital, Singapore 169856, Singapore; georgehsy@gmail.com (G.H.); siting.goh@mohh.com.sg (S.G.); lim.kiat.hon@singhealth.com.sg (T.K.H.L.)

3 Department of Urology, Singapore General Hospital, Singapore 169854, Singapore; alvin.low@mohh.com.sg (A.W.X.L.); tay.kae.jack@singhealth.com.sg (K.J.T.)

4 Institute of Molecular and Cell Biology (IMCB), Agency for Science, Technology and Research (A*STAR), Singapore 138673, Singapore

* Correspondence: yeongps@imcb.a-star.edu.sg (J.Y.); khor.li.yan@singhealth.com.sg (L.Y.K.); tongseng.lim@mbiomarkers.com (T.S.L.)

Simple Summary: Urothelial carcinoma (UC) is the most frequently diagnosed cancer of the urinary tract and is ranked the sixth most diagnosed cancer in men worldwide. About $70-75 \%$ of newly diagnosed UCs are non-invasive or low grade. Different tests such as urine cytology and cystoscopy are used to detect UC. If abnormal tissue is found during cystoscopy, then a biopsy will be performed. Cytology has low sensitivity for low-grade cancer while cystoscopy is invasive and costly. Detecting UC early improves the chances of treatment success. Therefore, many researchers have painstakingly identified urine biological markers for non-invasive UC diagnosis. In this review, we summarize some of the latest and most promising biological markers (including FDA-approved and investigational markers). We also discuss some new technologies that can aid research efforts in biological marker discovery for early UC detection.

Abstract: Urothelial carcinoma (UC) is the most frequent malignancy of the urinary system and is ranked the sixth most diagnosed cancer in men worldwide. Around 70-75\% of newly diagnosed UC manifests as the non-muscle invasive bladder cancer (NMIBC) subtype, which can be treated by a transurethral resection of the tumor. However, patients require life-long monitoring due to its high rate of recurrence. The current gold standard for UC diagnosis, prognosis, and disease surveillance relies on a combination of cytology and cystoscopy, which is invasive, costly, and associated with comorbidities. Hence, there is considerable interest in the development of highly specific and sensitive urinary biomarkers for the non-invasive early detection of UC. In this review, we assess the performance of current diagnostic assays for UC and highlight some of the most promising biomarkers investigated to date. We also highlight some of the recent advances in single-cell technologies that may offer a paradigm shift in the field of UC biomarker discovery and precision diagnostics.

Keywords: single cell; diagnostics; urothelial carcinoma; biomarker; non-invasive; cytology; cystoscopy; circulating tumor cells

\section{Introduction}

Bladder cancer (BC) is among the top 10 most common types of cancer worldwide, with around 550,000 new cases annually [1], and confers the highest financial burden to developed countries. BC accounts for around 3\% of all new cancer diagnoses and $2.1 \%$ of all cancer-associated deaths [2], ranking it 6th highest in men and 17th in women worldwide 
in terms of absolute incidence. Among the 550,000 new BCs diagnosed globally in 2018, around 425,000 (77\%) occurred in men and over 125,000 cases (23\%) occurred in women [3].

The World Health Organization's 2016 classification states that the three most common BCs are urothelial carcinoma (UC), squamous cell carcinoma, and adenocarcinoma. Among these, UC is the most common form, accounting for $90-95 \%$ of BC cases. BC is pathologically staged as non-invasive, stromal invasive, and muscle invasive.

Different tests and procedures are used to diagnose UC. The current diagnostic technologies include urinalysis, cystoscopy, urine cytology, biopsy, urine-based biomarkers, and clinical imaging such as computerized tomography (CT) urogram or retrograde pyelogram. Urine cytology is inexpensive and commonly used for initial detection of malignant cells, whereas cystoscopy with biopsy confirms the presence of the tumor [4] and allows for pathologic staging. While urine cytology is a useful tool for detecting high-grade UCs (up to $85 \%$ and $88 \%$ sensitivity and specificity, respectively), the sensitivity for the detection of low-grade UCs remains very low (10-43.6\%). Cystoscopy has a low diagnostic accuracy, especially with flat urothelial carcinoma in situ (CIS), which is missed in up to $20 \%$ of all cases [4]. Cystoscopy can also be unreliable for distinguishing between benign reactive lesions and malignant lesions, particularly in cases of prior transurethral resection (TUR) or intravesical therapy [5].

New endoscopic technologies, such as fluorescence cystoscopy, narrow-band imaging, confocal laser endomicroscopy (CLE), and optical coherence tomography have been developed to improve the rate and accuracy of detection, although these techniques are invasive, expensive, and time-consuming [5]. Therefore, the development of novel non-invasive urinary tests to detect UC-specific biomarkers has increased over the last few decades [6-8].

The present review provides details of the current FDA-approved diagnostic assays for UC and examines some of the emerging and novel biomarkers (Figure 1, Tables 1 and 2). While some studies are still in the preliminary stages, the purpose of this review is to highlight promising biomarkers with potential future diagnostic use in the clinic.

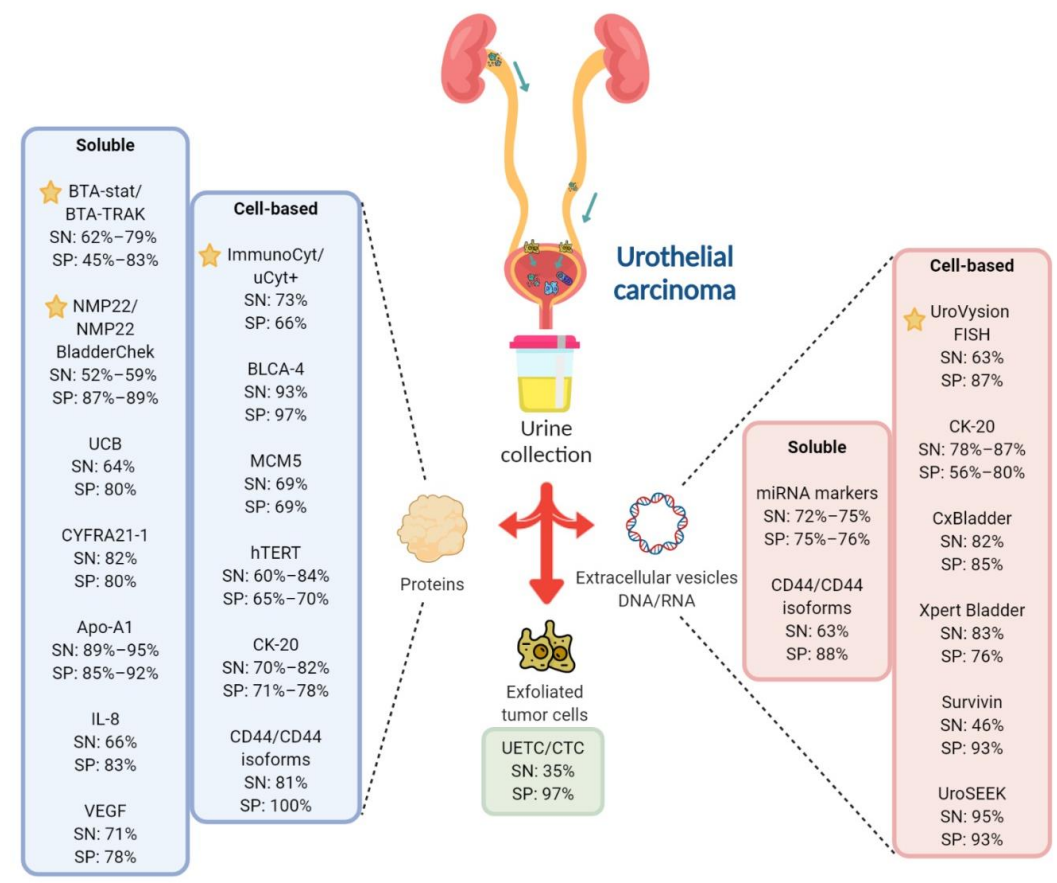

Figure 1. Overview of the FDA-approved and investigational urinary biomarkers for UC diagnosis. Most biomarkers, both soluble and cell-based, aims to detect either exfoliated tumor cells, protein or DNA/RNA changes in urine samples. Some of the promising investigational urinary biomarkers for UC and their sensitivity/specificity are shown and compared against the FDA-approved in-vitro diagnostic (IVD) tests. indicates FDA-approved IVD tests. $\star$ Created with Biorender.com. 
Table 1. FDA-approved urinary biomarkers for urothelial carcinoma (UC) in-vitro diagnosis.

\begin{tabular}{|c|c|c|c|c|c|c|c|c|c|c|}
\hline Test & Biomarker & Type & $\begin{array}{l}\text { Sample } \\
\text { Material }\end{array}$ & Method & $\begin{array}{l}\text { SN } \\
(\%)\end{array}$ & $\begin{array}{l}\mathrm{SP} \\
(\%)\end{array}$ & $\begin{array}{c}\mathrm{P} \\
(\mathrm{n})\end{array}$ & $\begin{array}{c}c \\
\text { (n) }\end{array}$ & Remark & Reference \\
\hline BTA-stat & \multirow{3}{*}{$\begin{array}{l}\text { Human complement factor } \\
\text { H-related protein }\end{array}$} & Soluble & Protein & $\begin{array}{l}\text { Dipstick immunoassay or } \\
\text { POC test }\end{array}$ & $64-69 *$ & $73-77^{*}$ & 3175 & - & \multirow{3}{*}{ High false positive rates } & $\begin{array}{c}{\left[\begin{array}{c}{[9]} \\
\text { (melta- } \\
\text { analysis) }\end{array}\right.} \\
\end{array}$ \\
\hline \multirow[b]{2}{*}{ BTA-Trak } & & \multirow[b]{2}{*}{ Soluble } & \multirow[b]{2}{*}{ Protein } & \multirow[b]{2}{*}{ ELISA } & 79 & 83 & 64 & 63 & & {$[8]$} \\
\hline & & & & & $62-71$ * & $45-81^{*}$ & 829 & - & & $\begin{array}{c}{[10]} \\
\text { (meta- } \\
\text { analysis) }\end{array}$ \\
\hline $\begin{array}{c}\text { NMP22/ } \\
\text { NMP22 BladderChek }\end{array}$ & NMP22 & Soluble & Protein & $\begin{array}{l}\text { ELISA or } \\
\text { POC test }\end{array}$ & $52-59$ * & $87-89 *$ & 5291 & - & $\begin{array}{l}\text { Better at detecting high-grade UC; false positives in } \\
\text { hematuria or inflammatory bladder conditions }\end{array}$ & 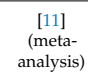 \\
\hline$\underset{\text { uCyt+ }}{\text { Immuno-cyt/ }}$ & $\begin{array}{l}\text { High-MW form of glycosylated CEA and } \\
\text { mucin-like antigen }\end{array}$ & Cellular & Protein & Immunocyto chemistry & $73 *$ & $66^{*}$ & 1602 & - & $\begin{array}{l}\text { Unaffected by hematuria or inflammatory } \\
\text { conditions; superior sensititivity to detecterearly } \\
\text { pathologicas stage than cytology, test resulth highhly } \\
\text { dependent on specimen stability and handling }\end{array}$ & $\begin{array}{c}{[12]} \\
\text { (meta- } \\
\text { analysis) } \\
\end{array}$ \\
\hline UroVysion FISH & $\begin{array}{l}\text { Aneuploidy for chromosomes } 3,7 \text {, and } 17, \\
\text { and loss of } 9 \text { p21 locus }\end{array}$ & Cellular & DNA & FISH & $63^{*}$ & $87^{*}$ & 3445 & - & 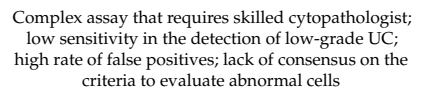 & $\begin{array}{c}\begin{array}{c}{[13]} \\
\text { (meta- } \\
\text { analysis) }\end{array} \\
\text { and }\end{array}$ \\
\hline
\end{tabular}

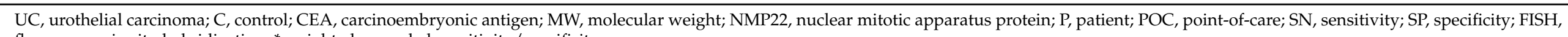
fluorescence in situ hybridization. * weighted or pooled sensitivity/specificity.

Table 2. Novel/investigational urinary biomarkers for UC diagnosis.

\begin{tabular}{|c|c|c|c|c|c|c|c|c|c|c|}
\hline $\begin{array}{c}\text { Biomarker/ } \\
\text { Test }\end{array}$ & Description & Type & $\begin{array}{l}\text { Sample } \\
\text { Material } \\
\end{array}$ & Method & $\begin{array}{l}\mathrm{SN} \\
(\%)\end{array}$ & $\begin{array}{l}\mathrm{SP} \\
(\%)\end{array}$ & $\begin{array}{l}P \\
(\mathbf{p})\end{array}$ & $\begin{array}{c}\mathrm{C} \\
(\mathrm{n}) \\
\end{array}$ & Remarks & References \\
\hline BLCA-4 & Nuclear transcription factor & Cellular & Protein & ELISA & $93 *$ & $97 *$ & \multicolumn{2}{|c|}{1119 (total participants) } & $\begin{array}{l}\text { High sensitivity and specificity for UC detection; } \\
\text { further validation required }\end{array}$ & $\begin{array}{c}{[14]} \\
\text { (meta- } \\
\text { analysis) }\end{array}$ \\
\hline MCM5 ${ }^{-}$ & $\begin{array}{l}\text { MCM family of proteins that assemble into } \\
\text { hexameric complexes with DNA helicase activity; } \\
\text { vital for DNA synthesis }\end{array}$ & Cellular & Protein & $\begin{array}{l}\text { Immuno- } \\
\text { fluorometric assay }\end{array}$ & 69 & 69 & 210 & 1354 & $\begin{array}{l}\text { Mix of low and high-grade patients; higher } \\
\text { sensitivity but similar specificity compared } \\
\text { with yytology }\end{array}$ & [15] \\
\hline \multirow[t]{2}{*}{ hTERT ${ }^{\wedge}$} & \multirow{2}{*}{$\begin{array}{l}\text { Catalytic subunit of telomerase, } \\
\text { a ribonucleoprotein that synthesizes telomeres at } \\
\text { the ends of chromosomess thus ensuring } \\
\text { genomic stability }\end{array}$} & \multirow[t]{2}{*}{ Cellular } & \multirow[t]{2}{*}{ Protein } & \multirow[t]{2}{*}{ Immunocytochemistry } & 84.8 & 65.2 & 101 & - & \multirow{2}{*}{ 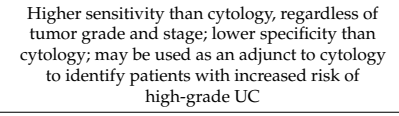 } & [16] \\
\hline & & & & & 60.6 & 70.4 & 500 & - & & {$[17]$} \\
\hline $\mathrm{CTCs}^{\wedge}$ & $\begin{array}{l}\text { Malignant epithelial cells that are shed from the } \\
\text { primary tumor into bodily fluids }\end{array}$ & Cellular & Protein & $\begin{array}{l}\text { Immuno magnetic enrichment } \\
\text { (Cellsearch) }\end{array}$ & $35^{*}$ & $97 *$ & 2161 & - & $\begin{array}{l}\text { The only FDA-approved CTC test; Possibility of } \\
\text { staining with different antibodies which allows } \\
\text { for the identification of new CTC biomarkers }\end{array}$ & $\begin{array}{c}{[18]} \\
\text { (meta- } \\
\text { analysis) }\end{array}$ \\
\hline \multirow{4}{*}{ CK-20 } & \multirow{4}{*}{$\begin{array}{l}\text { Cytokeratins are components of cytoplasmic } \\
\text { intermediate filaments found ine epithelial cells; } \\
\text { CK-20 is expressed in urothelial carcinoma but } \\
\text { not normal urothelial cells }\end{array}$} & \multirow{4}{*}{ Cellular } & \multirow{3}{*}{ Protein } & \multirow{3}{*}{$\begin{array}{l}\text { Immuno- } \\
\text { staining }\end{array}$} & 70 & 71 & 42 & 17 & \multirow{3}{*}{$\begin{array}{l}\text { Higher sensitivity than urine cytology as a UC } \\
\text { screening test, especially for low-grade } \\
\text { low-stage tumor }\end{array}$} & [19] \\
\hline & & & & & 80 & 78 & 50 & 20 & & [20] \\
\hline & & & & & 82 & 77 & 174 & - & & [21] \\
\hline & & & RNA (mRNA) & RT-PCR & $78-87$ & $56-80$ & 3473 & - & Poor performance for low-grade tumors & (pooled analysis) \\
\hline CxBladder & $\begin{array}{l}\text { mRNA expression of genes (IIFF, HOXA, MDK, } \\
\text { CDC, and IL8R) }\end{array}$ & Cellular & RNA (mRNA) & RT-qPCR & 82 & 85 & 66 & 419 & $\begin{array}{l}\text { Can distinguish between low-grade Ta tumors } \\
\text { and other detected UC with high sensitivity } \\
\text { and specificity }\end{array}$ & [23] \\
\hline $\begin{array}{c}\text { Xpert } \\
\text { Bladder }\end{array}$ & $\begin{array}{l}\text { mRNA expression of genes (CRH, IGF2, UPK1B, } \\
\text { ANXA10, and ABL1) }\end{array}$ & Cellular & RNA (mRNA) & RT-qPCR & 83 & 76 & 239 & 508 & Mainly high-grade patients & [24] \\
\hline
\end{tabular}


Table 2. Cont.

\begin{tabular}{|c|c|c|c|c|c|c|c|c|c|c|}
\hline $\begin{array}{c}\text { Biomarker/ } \\
\text { Test }\end{array}$ & Description & Type & $\begin{array}{l}\text { Sample } \\
\text { Material }\end{array}$ & Method & $\begin{array}{l}\text { SN } \\
(\%)\end{array}$ & $\begin{array}{ll}\mathrm{SP} \\
(\%)\end{array}$ & $\begin{array}{l}\mathrm{P} \\
(\mathrm{n})\end{array}$ & $\begin{array}{c}\mathrm{C} \\
(\mathrm{n})\end{array}$ & Remarks & References \\
\hline Survivin & Inhibitor of apoptosis gene & Cellular & DNA & Bio-dot test & 64 & 93 & 117 & 92 & $\begin{array}{l}\text { High sensitivity for detecting low-stage and } \\
\text { low-grade UC; more accurate than cytology and } \\
\text { NMP22 test; requires further validation }\end{array}$ & [25] \\
\hline UroSEEK & $\begin{array}{l}\text { Mutations in FGFR3, TP53, ERBB2, CDKN2A, } \\
\text { KRAS, HRAS, MET, PIK3CA, MLL, and VHL } \\
\text { and TERTp alterations }\end{array}$ & Cellular & DNA & $\begin{array}{l}\text { Massively parallel sequencing- } \\
\text { based assay (NGS/ } \\
\text { Sanger sequencing) }\end{array}$ & 95 & 93 & 570 & - & $\begin{array}{l}\text { Higher performance than urine cytology in } \\
\text { low-grade tumors }\end{array}$ & [26] \\
\hline \multirow{2}{*}{ AssureMDX } & \multirow{2}{*}{$\begin{array}{l}\text { Mutation analysis in FGFR3, TERT, and HRAS } \\
\text { genes and methylation analysis in OTX1, } \\
\text { ONECUT2, and TWIST1 genes }\end{array}$} & \multirow{2}{*}{ Cellular } & \multirow{2}{*}{ DNA } & \multirow{2}{*}{ PCR } & 93 & 86 & 97 & 103 & Mix of high and low-grade patients tested & [27] \\
\hline & & & & & $57-83$ & 59 & 977 & - & Patients with primary NMIBC & [28] \\
\hline $\mathrm{UBC}^{-}$ & $\begin{array}{l}\text { Soluble fragments of cytoskeletal } \\
\text { proteins } 8 \text { and } 18\end{array}$ & Soluble & Protein & ELISA or POC assay & $64.4^{*}$ & $80.3^{*}$ & 753 & 1072 & $\begin{array}{l}\text { Increased sensitivity when used in combination } \\
\text { with cytology; allows separation of } \\
\text { high vs. low-grade UC }\end{array}$ & {$[7,29]$} \\
\hline \multirow{3}{*}{ Apo-A1 } & \multirow{3}{*}{ Major high-density lipoprotein } & \multirow{3}{*}{ Soluble } & \multirow{3}{*}{ Protein } & \multirow{3}{*}{ ELISA } & 89 & 85 & 223 & 153 & \multirow{3}{*}{$\begin{array}{l}\text { Apolipoproteins are abundant in plasma; hence, } \\
\text { urinary concentrations are affected by hematuria }\end{array}$} & [31] \\
\hline & & & & & 91.6 & 85.7 & 40 & 24 & & [32] \\
\hline & & & & & 95 & 92 & 86 & 62 & & [33] \\
\hline IL-8 & $\begin{array}{l}\text { Leukocyte chemoattractant and angiogenic factor } \\
\text { associated with inflammation and carcinogenenesis }\end{array}$ & Soluble & Protein & ELISA & $66.4^{*}$ & $83.1 *$ & 225 & 273 & $\begin{array}{l}\text { Urinary concentrations elevated in urothelial } \\
\text { cell carcinoma }\end{array}$ & {$[34-37]$} \\
\hline VEGF & Tumor angiogenesis factor & Soluble & Protein & ELISA & $71.4 *$ & $78.1^{*}$ & 509 & 389 & Secreted in urine by UC cells & {$[8,34,35,38-40]$} \\
\hline CCL18 & $\begin{array}{c}\text { Cytokine involved in immunoregulatory and } \\
\text { inflammatory processes; promotes cancer } \\
\text { cells invasiveness }\end{array}$ & Soluble & Protein & ELISA & 88 & 86 & 64 & 63 & 55 high-grade, 9 low-grade & [41] \\
\hline sFAS & Anti-apoptotic protein released by UC cells & Soluble & Protein & ELISA & 88 & 89.1 & ${ }_{117}$ & 74 & $\begin{array}{l}\text { Better sensitivity in detecting low-grade } \\
\text { UC than cytology }\end{array}$ & [43] \\
\hline \multirow{2}{*}{ miRNA markers } & \multirow{2}{*}{$\begin{array}{l}\text { Short non-coding RNAs that regulate gene } \\
\text { expression by acting at the } \\
\text { post-transcriptional level }\end{array}$} & \multirow{2}{*}{$\begin{array}{l}\text { Soluble or } \\
\text { cellular }\end{array}$} & \multirow{2}{*}{ RNA (miRNA) } & \multirow{2}{*}{ RT-PCR/NGS } & $75^{*}$ & $75^{*}$ & 719 & 494 & \multirow{2}{*}{$\begin{array}{l}\text { Multi-miRNA assays have higher diagnostic } \\
\text { sensitivity than single miRNA assays }\end{array}$} & $\begin{array}{c}{\left[\begin{array}{l}{[44]} \\
\text { (neta- } \\
\text { analysis) }\end{array}\right.} \\
\end{array}$ \\
\hline & & & & & $72 *$ & $76^{*}$ & 1556 & 1347 & & $\begin{array}{c}{\left[\begin{array}{c}{[45]} \\
\text { (meta- } \\
\text { analysis) }\end{array}\right.} \\
\end{array}$ \\
\hline \multirow{2}{*}{$\begin{array}{l}\text { CD44/CD44 } \\
\text { isoforms }\end{array}$} & \multirow{2}{*}{$\begin{array}{l}\text { Ubiquitously expressed transmembrane } \\
\text { glycoprotein involved in cell-cell interactions, } \\
\text { cell adhesion and migration }\end{array}$} & Soluble & RNA (mRNA) & RT-PCR & 63.1 & 88.9 & 136 & 20 & $\begin{array}{c}111 \text { histological diagnosed UC, } 25 \text { benign } \\
\text { urological disorders }\end{array}$ & [46] \\
\hline & & Cellular & Protein & ELISA & 81 & 100 & 65 & 53 & $\begin{array}{l}\text { Presence of hematuria can interfere } \\
\text { with the assay }\end{array}$ & {$[47]$} \\
\hline
\end{tabular}

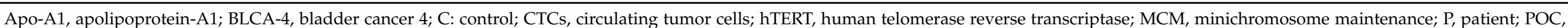

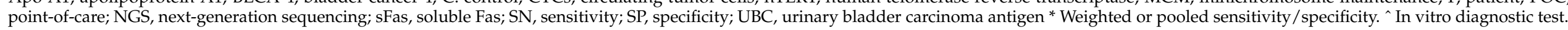




\section{Current Research Gaps in UC Diagnosis}

Around $70-75 \%$ of newly diagnosed UC cases are non-muscle invasive bladder cancer (NMIBC). The current gold standard NMIBC treatment is surgical removal via TUR. Due to the high rate $(\sim 70 \%)$ of recurrence after TUR, patients require an intensive follow-up regime that lasts many years following the initial diagnosis. This lifelong requirement for disease surveillance means UC is associated with the highest cost from diagnosis to death [48].

Urine cytology has high sensitivity in detecting high grade urothelial tumors (84\%), but low sensitivity in low-grade tumors (16\%) [49]; hence, urine cytology can miss lowgrade NMIBC tumors. While cystoscopy remains the gold standard evaluation modality in the diagnosis of UC, it is invasive, costly, and the procedure is uncomfortable for the patient. Urine biomarkers offer a non-invasive approach to detect UC, especially for high-grade lesions and CIS, with higher sensitivity but lower specificity than urine cytology [50].

The Food and Drug Administration (FDA) has approved six urinary assays for clinical in-vitro diagnostic (IVD) use: BTA-stat, BTA-TRAK, NMP22, NMP22 BladderChek, ImmunoCyt/uCyt+, and UroVysion fluorescence in situ hybridization (FISH) (Table 1). While these FDA-approved IVD tests show high sensitivity in the detection of high-grade and late-stage UC, they are unable to detect low-grade malignancies and tend to give false positive results for benign inflammatory conditions. As such, they cannot be used as stand-alone diagnostic tests for UC and are used in conjunction with urine cytology or other diagnostic tests.

Novel and emerging biomarkers are continuously being developed and have shown higher sensitivity, specificity, and accuracy than urine cytology and current FDA-approved tests (Table 2). However, their use in clinical practice requires validation studies using independent cohorts and long-term follow-up. At present, there is no non-invasive biomarker that has been recommended to replace the gold standard methods currently used to detect UC.

\section{FDA-Approved and Investigational UC Biomarkers}

In the following sub-sections, we highlight the various FDA-approved IVD tests and some promising emerging/novel biomarkers for UC diagnosis.

\subsection{FDA-Approved IVD Tests for UC Diagnosis}

Increasing research efforts have been placed in identifying a suitable urinary biomarker to reduce the necessity of invasive cystoscopy. The various FDA-approved tests are a major step towards this direction. However, the inclusion of large proportions of high-grade tumors inflates the sensitivity and specificity of many FDA-approved tests, and thus the problem of identifying low grade tumors remains.

\subsubsection{Bladder Tumor Antigen (BTA) Assay}

The BTA-TRAK and BTA-stat kits use sandwich immunoassay and the colorimetric antigen-antibody reaction, respectively, to detect human complement factor H-related protein in urine. These soluble factors are secreted by bladder tumor cells during stromal invasion and inhibit the complement cascade to prevent cell lysis, which may allow tumor cells to escape host immunity [51]. The BTA-TRAK kit is a quantitative test that requires processing in a suitably equipped laboratory, whereas the BTA-stat kit provides immediate qualitative results. The BTA-TRAK and BTA-stat kits have a sensitivity of around $65 \%$ and specificity of 74-77\% [13,52]. A meta-analysis of 13 studies that reviewed 3175 patients found the sensitivity and specificity of the BTA-stat kit to be $64-69 \%$ and $73-77 \%$, respectively [9]. However, the studies included in this meta-analysis mainly compared individuals with high-grade UC with control groups. Goodison et al. reported a sensitivity of $79 \%$ and specificity of $83 \%$ for the BTA-TRAK kit [8]. This was supported by a meta-analysis of five studies including individuals with either low or high-grade UC [10]. However, as complement factor H-related protein is also found in the blood and is not unique to UC, other causes of hematuria, such as post-treatment hematuria (e.g., intravesical chemotherapy or immunotherapy), infection, or recent instrumentation, 
can result in false positives that may significantly decrease the specificity of these kits. Despite this limitation, these tests have been approved by the FDA for the detection of UC in symptomatic patients or those under surveillance for UC.

\subsubsection{Nuclear Matrix Protein 22 (NMP22)}

The NMP22 test kit uses a colorimetric antigen-antibody technique to detect NMP22 in urine. NMP22 is a biomarker that is derived from urothelial cell death and is elevated in the urine of UC patients [53]. Data from 19 studies and 23 systemic reviews suggest a sensitivity of $52-59 \%$ and specificity of $87-89 \%$ [11]. Similar to the BTA-TRAK and BTA-stat kits, the NMP22 test kit is also prone to false positive results as NMP22 is released during apoptosis, which also occurs during infection and inflammation, and is not specific to malignancy [54]. The quantitative NMP22 Bladder Cancer ELISA Test kit and the NMP22 BladderChek point-of-care (POC) test are FDA-approved for the detection and surveillance of UC.

\subsubsection{ImmunoCyt/uCyt+ Assay}

The ImmunoCyt test is a triple immunofluorescent monoclonal antibody assay that measures the glycosylated form of carcinoembryonic antigen (CEA) and two mucins (LDQ10 and M344) that are specifically found on malignant exfoliated urothelial cells [55]. ImmunoCyt reportedly has a sensitivity of $74-87 \%$ and specificity of $62-78 \%$, with a positive predictive value (PPV) of 26-67\% and negative predictive value (NPV) of 91-96\% [56,57]. In agreement with this, a meta-analysis by He et al. reported a sensitivity of $73 \%$ and specificity of $66 \%$ [12]. False positives due to infection and inflammation [e.g., following bacillus Calmette-Guérin (BCG) treatment] affect the specificity of the kit. He et al. reported that the ImmunoCyt test had a higher sensitivity, but lower specificity than the urine cytology test. The ImmunoCyt kit can be combined with urine cytology as a surveillance tool as it has $\sim 80 \%$ sensitivity for low-grade tumors and almost 100\% sensitivity for high-grade tumors [55].

\subsubsection{UroVysion FISH}

The UroVysion FISH test detects genetic markers, specifically aneuploidy for chromosomes 3, 7, and 17, and loss of 9p21 locus. In a meta-analysis, the reported sensitivity and specificity were $63 \%$ and $87 \%$, respectively [13]; however, it lacks sensitivity for low-grade UC. UroVysion FISH is FDA-approved and seems to be useful for predicting recurrence in the setting of a negative surveillance cystoscopy and "atypical" urine cytology [58] as well as other specific scenarios. Some examples include disease recurrence detection with an "atypical" cytology following intravesical BCG treatment of high-grade NMIBC and diagnosis of upper urinary tract UC in an "atypical" upper tract washing cytology. Pitfalls of UroVysion FISH include the complexity of the assay and the requirement for a skilled cytopathologist, a high false-positive rate, and a lack of consensus on the criteria to evaluate abnormal cells.

\subsection{Novel/Investigational Biomarkers for UC Detection}

Some novel candidate biomarkers have been identified that require further validation and, as such, are not yet FDA-approved. The sensitivity and specificity of some of these markers are better than urine cytology or current FDA-approved tests, especially for lowgrade tumors. These investigational biomarkers are grouped into two categories: cell-based and soluble. We discuss the biomarkers belonging to these two categories in the sections below, as well as CD44/CD44 isoforms and microRNA (miRNA) markers that can be classified as either cell-based or soluble.

\subsubsection{Cell-Based Biomarkers}

Cell-based biomarkers rely on the detection of urine exfoliated tumor cells (UETCs) or the proteins (surface or intracellular) or genomic content (DNA or RNA) of such cells. These include bladder cancer 4 (BLCA-4), minichromosome maintenance 5 (MCM5), human telomerase 
reverse transcriptase (hTERT), circulating tumor cells (CTCs), cytokeratin 20 (CK-20), CxBladder, Xpert Bladder, Survivin, UroSEEK, and AssureMDX. We discuss each of these cell-based urinary biomarkers and their diagnostic performance below.

\section{BLCA-4}

BLCA-4 is a nuclear transcription factor expressed in bladder tumors, especially during the early stages of the disease [14]. It is absent in healthy bladder tissue but has a high sensitivity in detecting low-grade UC. BLCA-4 can be measured using commercially available ELISAs. A meta-analysis of BLCA-4 in UC diagnosis involving 1119 individuals indicated a high pooled sensitivity (93\%) and specificity (97\%) [14]. However, larger prospective studies are required to translate this biomarker into clinical use.

\section{MCM5}

The MCM family of proteins assemble into hexameric complexes with DNA helicase activity and are vital for the initiation of DNA synthesis [59]. MCM proteins are dysregulated and overexpressed in hyperproliferative and malignant cells [60]. Increased MCM5 levels in the urine samples of patients, measured by immunofluorometric assay, is predictive of UC [61]. Kelly et al. demonstrated that MCM5 levels could be used to discriminate between patients with and without UC, with $69 \%$ sensitivity and specificity [15]. The MCM5 test has similar specificity but significantly higher sensitivity than cytology [15], and can detect all grades and stages of UC.

\section{hTERT}

Telomerase is a ribonucleoprotein that synthesizes telomeres at the ends of chromosomes, thus ensuring genomic stability [62]. Several tumors, including UC, are characterized by telomerase hyperactivity that protects the chromosomes of cancer cell and prevents them from dying. In a retrospective analysis of 101 cell blocks from UC patients, Khalbuss and Goodison reported that hTERT showed a higher diagnostic sensitivity $(84.8 \%)$ but lower specificity $(65.2 \%)$ than cytology ( $65 \%$ and $\sim 95 \%$, respectively) [16]. Allison et al. evaluated the performance of hTERT in 500 urinary tract cytology specimens and reported a sensitivity of $60.6 \%$ and specificity of $70.4 \%$ [17]. Overall, hTERT could be used as an adjunct to urine cytology to aid the identification of patients with an increased risk of high-grade UC.

\section{CTCs/UETCs}

CTCs or urine exfoliated tumor cells (UETCs) are malignant epithelial cells that are shed from the primary tumor into bodily fluids (e.g., urine) and can be indicative of micrometastatic disease [63]. CTCs may harbor important information about the primary tumor that could have important prognostic and diagnostic value. CTCs are detected in clinical settings using immunocytochemistry, reverse-transcription polymerase chain reaction (RT-PCR), flow cytometry, or the CellSearch system, which is the only FDAapproved CTC test. It is well established that the presence of CTCs is an indicator of poor prognosis in breast, colorectal, and gastric cancers [64-67]. A meta-analysis of 30 published studies involving 2161 UC patients showed that CTC positivity was significantly associated with tumor stage, histological grade, metastasis, and lymph node metastasis [68]. It was also significantly associated with poor overall survival, progression/disease-free survival, and cancer-specific survival. As CTC detection in UC has relatively low sensitivity (35\%) but high overall specificity (97\%), it is not currently used as a screening/diagnostic test; however, it is used as a method to confirm UC diagnosis $[68,69]$. The ability to conjugate different antibodies to Ferrofluid in the CellSearch system may allow for the identification of new CTC biomarkers for more sensitive detection. Further well-designed, large-scale prospective studies are required to determine the potential use of CTCs as a biomarker for UC diagnosis. 
Cytokeratins belong to a family of $>20$ intermediate filament proteins that are expressed in epithelial cells. CK-20 is expressed in UC but not normal urothelial cells and is measured non-invasively in urine via RT-PCR or immunostaining. It has also been reported as a biomarker for UC detection. A meta-analysis of 27 diagnostic studies reviewing 3473 participants concluded that the urine CK-20 test had a pooled sensitivity of $78-87 \%$ and specificity of $56-80 \%$ [22], but showed poor performance for low-grade disease. Other reports, however, showed that CK-20 positive atypical urothelial cells were indicators of low-grade UC [70-72]. CK-20 immunostaining for UC detection showed good sensitivity $(70-82 \%)$ and specificity $(71-78 \%)$, indicating the potential use of CK-20 as a biomarker for UC detection [19-21].

\section{CxBladder}

CxBladder is a clinically validated multiplex mRNA test used to measure the urine concentration of five RNA markers (CDC2, HOXA13, MDK, IGFBP5, and CXCR2) in UC patients [73]. CXCR2 is expressed by neutrophils and its levels are increased in non-malignant inflammation that increases the cellularity of voided urine samples [23]. The measurement of CXCR2 levels is hypothesized to reduce the chance of false-positive results in patients with acute or chronic urothelial inflammation. The expression levels of these five RNA markers are determined by quantitative RT-PCR (RT-qPCR). O'Sullivan et al. reported that CxBladder has a sensitivity of $82 \%$ and specificity of $85 \%$ [23]. CxBladder can detect high-grade tumors with a higher accuracy than current FDA-approved NMP22 tests and cytology. Importantly, Cxbladder can distinguish between low-grade Ta stage tumors and other UCs with a sensitivity of $91 \%$ and specificity of $90 \%$, respectively.

\section{Xpert Bladder}

Xpert Bladder Cancer Monitor (Xpert) measures the expression of five mRNA targets (ABL1, CRH, IGF2, UPK1B, and ANXA10) that are often overexpressed in NMIBC and are detected in voided urine samples [24]. The assay is performed in a self-contained cartridge using the GeneXpert System, which automates and integrates cell lysis, nucleic acid amplification, and target sequence detection using RT-qPCR. It is a fast, easy-touse, and robust assay. A study of 239 patients by Valenberg et al. found that the Xpert assay had a sensitivity of $76 \%$ and specificity and $85 \%$ [24]. The Xpert assay has a higher sensitivity and NPV than cytology and UroVysion FISH; however, the specificity seems to be only marginally higher than UroVysion FISH and lower than cytology. The Xpert assay has high NPVs of $93 \%$ and $98 \%$ and thus might make an important contribution to monitoring patients with NMIBC. A high NPV suggests that urologists can consistently exclude diseases with negative results and reduce the number of invasive cystoscopies for intermediate-to-high-risk NMIBC, thus reducing costs and patient discomfort [4].

\section{Survivin}

Survivin is an anti-apoptotic protein that is almost exclusively expressed in the malignant epithelium [74]. Survivin and NMP22 levels were measured by Shariat et al. in voided urine samples from 117 UC patients undergoing cystoscopy and 92 control individuals [25]. They found that survivin displayed higher sensitivity (64\%), specificity (93\%), PPV (92\%), and NPV (67\%) than NMP22 or urine cytology. Higher levels of survivin were also associated with more advanced histologic grades [75]. As this is the only published study to-date to evaluate the role of urinary survivin in the follow-up of NMIBC, this assay remains experimental and requires further development and validation.

\section{UroSEEK}

UroSEEK is a novel, non-invasive urine-based biomarker that is measured by applying massively parallel sequencing to cellular DNA to detect UC mutations involving the TERT gene promoter and 10 other genes (FGFR3, TP53, CDKN2A, ERBB2, HRAS, KRAS, 
PIK3CA, MET, VHL, and MLL) combined with aneuploidy assessment [76]. These genes are involved in signaling pathways associated with NMIBC. Springer et al. reported that UroSEEK displayed high sensitivity and specificity (95\% and $93 \%$, respectively) and had a higher performance than urine cytology in low-grade tumors [26]. In an early detection setting, UroSEEK demonstrated high sensitivity and specificity ( $96 \%$ and $88 \%$, respectively), and had a significant lead time to clinical cancer diagnosis, as 7 out of 22 patients from an early detection cohort were detected 6 months prior to clinical diagnosis [76]. UroSEEK shows promising potential in diagnosing patients with atypical cytology.

\section{AssureMDX}

AssureMDX is a laboratory-developed test that identifies DNA mutations in three genes (FGFR3, TERT, and HRAS) and methylation in another three genes (OTX1, ONECUT2, and TWIST1) in urine samples [77]. In a large multicenter prospective study of 977 patients with primary NMIBC, the sensitivity for recurrent detection was $57 \%$ for low-grade tumors and $83 \%$ for high-grade tumors [28]. In another multicenter study involving 97 UC patients, AssureMDX demonstrated a sensitivity of $93 \%$ and specificity of $86 \%$ for UC diagnosis [27]. The AssureMDX assay thus shows potential as a diagnostic tool in patients with low-grade tumors to identify high-grade tumors earlier.

\subsubsection{Soluble Biomarkers}

UC cells can release soluble factors into the urine in the form of proteins or cell-free DNA/RNA contained in extracellular vesicles. A number of promising soluble biomarkers have been investigated, including urinary bladder carcinoma antigen (UBC), CYFRA211, apolipoprotein-A1 (Apo-A1), interleukin-8 (IL-8), vascular endothelial growth factor (VEGF), C-C motif chemokine 18 (CCL18), hyaluronic acid (HA) or hyaluronidase (HAse) and soluble Fas (sFas). We discuss each of these in details below.

\section{UBC Test}

The UBC test measures soluble fragments of cytokeratins 8 and 18 in urine; these factors have a role in tumor invasion [78]. The UBC test is available in two different formats: a quantitative ELISA-based assay (UBC IRMA) and a qualitative POC-based assay (UBC Rapid). The mean sensitivity and specificity reported in 11 studies involving 753 patients and 1072 controls were $64.4 \%$ and $80.3 \%$, respectively [7]. The overall sensitivity increased to $77.4 \%$ when used in combination with cytology [79]. Furthermore, high CK8 and CK18 levels detected in urine by the UBC Rapid test enable the distinction between high- and low-grade UC [29].

\section{CYFRA 21-1}

CYFRA 21-1 detects soluble cytokeratin 19 fragments by ELISA or immunoradiometric assay. Several studies have reported the ability of CYFRA 21-1 to distinguish between UC patients from controls, achieving sensitivity of $70-90 \%$ and specificity of $73-86 \%[7,30,80]$. Huang et al. conducted a meta-analysis of 16 studies, with a total of 1252 patients and 1233 controls [30]. The mean reported sensitivity and specificity of urinary CYFRA211 were $82 \%$ and $80 \%$, respectively. This assay has high sensitivity for the detection of high-grade and CIS tumors, but not for early detection.

Apo-A1

Apo-A1 is a major high-density lipoprotein that is highly expressed and secreted in UC patients [33,81]. In a study conducted on 223 patients with UC and 153 without UC, soluble Apo-1 urinary concentrations measured using commercial ELISA were significantly higher in UC patients compared with healthy individuals, with a sensitivity of $89 \%$ and specificity of $85 \%$ [31]. Another study by Chen et al. including 86 patients and 62 controls reported an even higher sensitivity (95\%) and specificity (92\%) [33]. In an early detection setting, Apo-A1 concentrations were shown to be increased in the urine of patients with low-grade 
transitional cell carcinoma (TCC) and increased further in aggressive UC [32]. The diagnostic sensitivity and specificity were $91.6 \%$ and $85.7 \%$, respectively. Apolipoproteins are moderately abundant in plasma and hence urinary concentrations could be influenced by hematuria. However, the high sensitivity and specificity of the Apo-A1 test, combined with its potential for early diagnosis highlights Apo-A1 as a promising diagnostic urinary biomarker for UC.

\section{IL-8}

Human IL-8 is a chemokine produced by bladder epithelial cells and is elevated in UC $[36,82,83]$. IL-8 levels in the urine of UC patients have shown a weighted sensitivity and specificity of $66.4 \%$ and $83.1 \%$, respectively, from the combined data of four studies [34-37]. Urinary IL-8 concentrations are elevated in patients with TCC compared with healthy controls, and increase with increasing stage but not grade, indicating a correlation between IL-8 production and tumor invasiveness or angiogenesis [36]. IL-8 has also been reported in other multianalyte panels, where it showed high sensitivity and specificity in detecting UC [8].

\section{VEGF}

VEGF is involved in tumor angiogenesis and is secreted into the urine by UC cells [84]. VEGF levels are measured by ELISA: elevated VEGF levels are associated with a higher disease recurrence risk in patients with previous NMIBC [85]. The weighted sensitivity and specificity reported in six different studies based on 509 patients and 389 controls were $71.4 \%$ and $78.1 \%$, respectively $[8,34,35,38-40]$. Similar to IL-8, VEGF has also been reported in several multianalyte panels for UC detection with high sensitivity and specificity [8].

\section{CCL18}

CCL18 is a soluble cytokine involved in immunoregulatory and inflammatory processes [41]. It promotes cancer cell invasiveness by triggering integrin clustering and enhancing adherence to the extracellular matrix [41]. CCL18 is measured using commercially available ELISAs. Urinary CCL18 is undetectable in most individuals without UC but is significantly expressed in patients with UC. CCL18 can differentiate between patients with UC and healthy individuals with a high sensitivity (88\%) and specificity (86\%) [41]. Most studies on CCL18 have focused on high-grade and high-stage disease, while studies in patients with low-grade and low-stage disease are limited.

\section{HA/HAse}

HA is a glycosaminoglycan that is involved in cell adhesion and proliferation and promotes tumor growth and metastasis. HAse is a glycosidase that mainly degrades HA into small fragments that promote tumor angiogenesis [86]. HA and HAse have been found to be elevated in the urine of UC patients measured using ELISA and RT-PCR/substrate (HA)-gel zymography, respectively. HA and HAse, both individually and combined, showed high potential diagnostic value as non-invasive urinary biomarkers [87,88]. A metaanalysis of five different studies including a total of 981 participants demonstrated that the HA-HAse test showed superior sensitivity $(90.8 \%)$ and specificity $(82.5 \%)$ than HA and HAse alone, indicating that the combined HA and HAse measurement has potential as a biomarker for UC detection [42]. Further validation in larger, multicenter trials is required to translate this test into clinical practice.

\section{sFAS}

Urinary sFas is a cleaved cell-surface receptor that belongs to the tumor necrosis factor protein family commonly expressed in UC [89]. The dysregulation of Fas-mediated apoptosis is hypothesized to lead to UC progression and development [89]. Serum sFas levels are reportedly three times higher in UC patients than healthy individuals. In a study performed by Srivastava et al., the measurement of urinary sFas concentrations showed high sensitivity 
$(88.0 \%)$ and specificity $(89.1 \%)$ in the diagnosis of TCC of urinary bladder for both primary and recurrent disease [43]. The measurement of urinary sFas also showed greater sensitivity in detecting low-grade UC compared with cytology ( $88.01 \%$ vs. $66.67 \%$, respectively).

\subsubsection{Cell-Based/Soluble Biomarker}

As mentioned, there are two potential biomarkers that can be classified as either cell-based or soluble. These biomarkers can be expressed by UETCs or they can be secreted extracellularly by proteolytic cleavage of the membranous form/alternative splicing (e.g., CD44/CD44 isoforms) or encapsulated into extracellular vesicles (e.g., miRNA markers).

\section{CD44/CD44 Isoform}

CD44 is cell surface adhesion protein that has important roles in various biological processes, including lymphocyte homing and activation, cell motility, and cell-matrix interactions [90]. Changes in CD44 expression levels are commonly associated with tumor invasion and metastasis [91]. A study involving 136 patients, including 111 histologically diagnosed with UC, showed an overall sensitivity and specificity of $63.1 \%$ and $88.9 \%$, respectively, for urinary CD44 [46]. Urinary CD44 was measured using RT-qPCR and was positively associated with tumor aggressiveness in UC. Woodman et al. showed that CD44 isoforms in protein lysates of exfoliated tumor cells in the urine (detected by ELISA) could be reliably detected in UC, with $81.1 \%$ sensitivity and $100 \%$ specificity [47]. The presence of hematuria can interfere with this assay but does not limit the clinical potential of this biomarker. Repeated testing and further validation are required to determine the potential use of CD44 as a promising biomarker for reliable, routine, and noninvasive detection of early UC.

\section{miRNA Markers}

miRNAs are short (21-23 nucleotides in length) non-coding RNAs that regulate gene expression at the post-transcriptional level. The diagnostic value of miRNAs in patients with UC has been reported in numerous studies (reviewed in [92]). Urinary miRNAs can be measured by RT-PCR in urine supernatants or sediments [44]. Recently, high-throughput miRNA profiling has been performed using next-generation sequencing (NGS) [93]. A multi-miRNA assay was reported to have higher diagnostic sensitivity than a single miRNA assay [94]. A meta-analysis of 23 studies, including 719 patients and 494 controls, was conducted to evaluate the diagnostic potential of miRNAs in UC, and showed that urinary miRNAs have a pooled sensitivity of $75 \%$ and specificity of $75 \%$ in diagnosing UC [44]. Another meta-analysis of 31 studies, including 1556 patients and 1347 controls, reported a sensitivity and specificity of $72 \%$ and $76 \%$, respectively [45]. miRNA assays may serve as potential diagnostic tools for UC; their clinical application now requires further validation in large prospective studies.

\section{Single-Cell Technologies}

Single-cell technology has made encouraging progress in recent years such that it now provides the means to detect, isolate, and analyze rare target cells such as CTCs, cancer stem cells, or pathogenic immune cells to ultimately guide individualized treatment strategies. Most single-cell technologies involve two steps: single-cell isolation and analysis (Figure 2).

Single-cell isolation is the upstream process required prior to single-cell analysis and includes: (1) marker/phenotype-based methods for isolating single cells from bulk cell populations (e.g., fluorescence-activated cell sorting, microfluidics, micromanipulation, and laser-capture microdissection) or from rare cell populations e.g., CellSearch (Menarini Silicon Biosystems), DEPArray (Menarini Silicon Biosystems), CellCelector (Automated Lab Solutions) and MagSweeper (Illumina Inc.), and (2) label-free approaches based on the biophysical properties of cells such as size, shape, density, and stiffness [e.g., nanofabricated filters (CellSieve) and ClearCell FX (Clearbridge BioMedics)]. 
Some single-cell technologies (e.g., $10 \times$ Genomics, Drop-Seq) do not isolate individual target cells prior to single-cell analysis. Instead, these technologies involve encapsulating single cells with single barcoded beads in nanoliter-sized droplets and allow ultra-highthroughput phenotyping and molecular characterization of all individually encapsulated cells in the samples. Cell identity is then inferred through reverse bioinformatics analysis of the high throughput data (e.g., transcriptome analysis).

Single-cell analysis reveals the heterogeneities in morphology, function, composition, and genetic make-up of apparently identical cells. Recent advances in single-cell analysis can overcome the difficulties arising in the diagnostics for a targeted model of disease due to cell heterogeneity. Single-cell analysis techniques include genomic (whole genome/whole exome), transcriptomic, epigenomic, proteomic, and metabolomic profiles of cancer cells. Among these, single-cell genomic analysis has shown the most encouraging progress $[18,95,96]$.

\section{Applications of Single-Cell Technologies for UC Diagnosis}

In UC, tumor cells that carry key genetic information of the primary tumor are shed directly by the growing tumor of the bladder into bodily fluids, such as blood or urine, making them a promising liquid biomarker for UC detection. However, in UC patients, the detection of UETCs is complicated by the presence of other urinary components such as normal urothelial cells, red blood cells, crystals, urinary cylinders, and other impurities. Furthermore, the extreme rarity and heterogeneity of CTCs/UETCs makes detecting these cells a challenging endeavor in UC diagnosis.

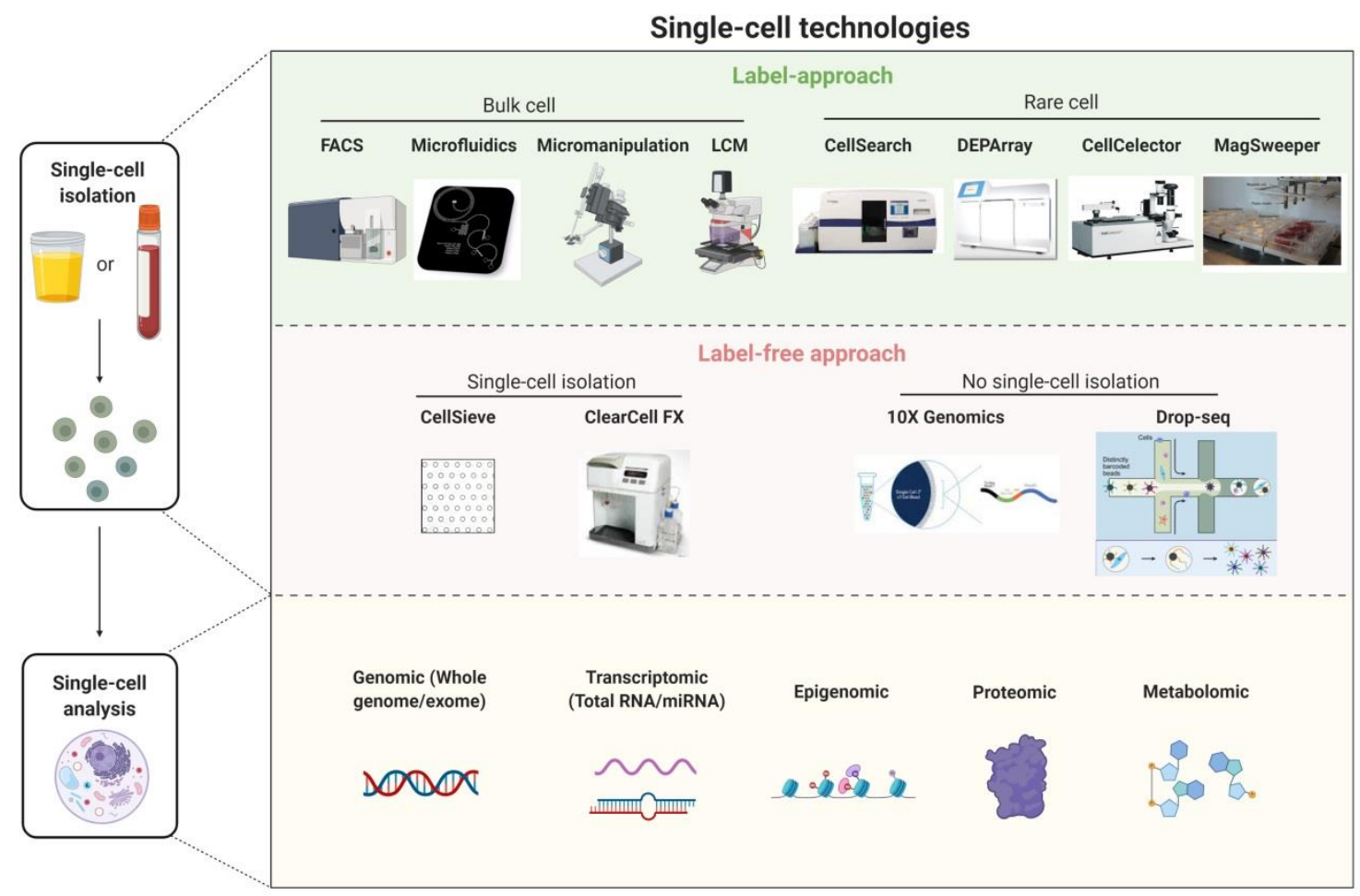

Figure 2. An overview of single-cell technologies. Single-cell technologies involve two steps: single-cell isolation followed by single-cell analysis. Single-cell isolation includes label approaches (e.g., FACS, microfluidics, micromanipulation, LCM, CellSearch, DEPArray, CellCelector, and MagSweeper) and label-free approaches (e.g., CellSieve and ClearCell FX). Some singlecell technologies such as $10 \times$ genomics and drop-seq do not involve single-cell isolation before single-cell analysis. Single-cell analysis techniques include genomics (whole genome/exome), transcriptomics (total RNA/miRNA), epigenomics, proteomics and metabolomics. FACS, flow assisted cell sorting, LCM, laser capture microdissection. Created with BioRender.com.

Advancements in single-cell technologies have increased the sensitivity and reliability of the methodologies for CTC detection, such as the CellSearch system and microfluidicbased techniques. CellSearch is an FDA-approved CTC test for the analysis of blood 
samples from patients with metastatic breast, prostate and colorectal cancer [97-100]. The CellSearch system has been successfully used to detect CTCs derived from patients with UC in multiple studies [68,101]. Although the number of patients enrolled and the sensitivity remains low, these early data provide a proof-of-concept for the identification of UETCs in UC patients using the CellSearch system. Microfluidic-based techniques to detect cancer cells in urine have also been recently developed and provide a novel approach to UC diagnosis. Several microfluidic devices that can detect rare UETCs have been developed [102,103], including a single-cell microscopic observation device for detecting tumor cells using droplet microfluidic technology [104].

Single-cell analysis can have broad applications in the UETC diagnostic workflow. Single-cell sequencing (SCS) such as whole-genome sequencing (WGS) was used by Chen et al. to analyze copy number aberrations (CNAs) in 12 UETCs captured using a novel microfluidic immunoassay approach [102]. The identities of the captured UETCs were successfully verified based on their genomic instability profiles, demonstrating the potential diagnostic capability of these methods for patients with UC. Single-cell miRNA profiling and single-cell epigenomic profiling also provide the exciting possibility of linking genetic and transcriptional heterogeneity in the context of cancer biology, leading to improved cancer diagnosis. The relative stability of miRNAs and DNA methylation has led to the development of diagnostic urinary biomarkers in UC [105-111]. Single-cell miRNA and epigenomic profiling have the potential to identify modifications specific to UETCs and thus guide the appropriate diagnosis. Finally, single-cell metabolomics analyses can detail the metabolic characteristics of UETCs at the single-cell level, thus identifying potential biomarkers that could be used for early UC diagnosis.

\section{Discussion and Future Perspectives}

The high recurrence rate and requirement for invasive diagnostic and monitoring methods, such as cystoscopy, makes UC the most expensive human cancer from diagnosis to death. While cystoscopy and urine cytology remain the gold standard for initial UC diagnosis and staging, there is a push to discover novel, non-invasive biomarkers for the diagnosis, prognosis, and follow-up of UC using liquid biopsy samples. As such, the past decade has seen the development of different diagnostic and monitoring systems for UC patients, based on gene expression or protein biomarkers in urine samples.

The degradation of cells, proteins, DNA, and RNA in urine samples depends on time and temperature, resulting in a different quantity and quality of cells and soluble factors, and thus highly variable sensitivities and specificities of such biomarkers in the urine. However, urinary biomarkers are attractive because the testing is non-invasive and cost-efficient, and the sample collection is easy compared to the invasive cystoscopy gold standard tests.

Urinary biomarkers, which can be either cellular or soluble, have their inherent advantages and disadvantages. Soluble biomarkers are easy to collect and the tests are usually carried out using simple laboratory techniques that are quick and relatively inexpensive. However, the main drawback of such techniques is low sensitivity. Furthermore, the original cellular source of these soluble biomarkers might not be obvious, and their stability varies depending on the types of biomarkers. On the other hand, cellular biomarkers are specific and allow single-cell analysis. Cellular biomarkers can be used for initial enrichment and/or isolation for further downstream molecular/metabolomic analyses. Such cellular biomarkers can also be used in combination with other visualization techniques (e.g., cystoscopy, IHC) to confirm the diagnosis. The major limitation of cellular biomarkers is the rarity of UETCs. Other drawbacks include the complexity of the techniques that often require highly skilled and trained personnel and specialized laboratories, and the associated high cost.

The current FDA-approved urinary biomarkers for the diagnosing and monitoring UC are unable to replace urine cytology due to their low sensitivity and specificity, particularly in detecting low-grade tumors (e.g., NMP22 test). Other tests have high costs that limit 
their use in daily clinical practice (e.g., UroVysion FISH). Several novel biomarkers have been identified that have the potential to detect NMIBC with high accuracy and NPV, outperforming conventional urine cytology methods in detecting low-grade tumors. In our opinion, urinary markers that have been trialed and tested in low grade NMIBC settings with sufficient sensitivity and specificity, such as hTERT, CK-20, CxBladder, Survivin, UroSEEK, AssureMDX, UBC, HA/HAse, and sFAS have great potential and could serve as powerful tools if they could be further developed, refined, and validated with large, randomized, and prospective cohort trials.

UC diagnosis can now leverage on single-cell technologies to detect, isolate, and analyze rare cancer cells such as CTCs and cancer stem cells or even pathogenic immune cells to ultimately guide individualized treatment strategies. Although emerging biomarkers are being continuously developed, especially for low-grade disease, there is still a significant lack of external validation using independent, large-scale cohorts with long-term follow up.

It is important to note that potential urinary biomarkers should complement, rather than substitute, conventional urine cytology and ultimately replace cystoscopy. This point is especially important for low-grade UC, given the fundamental weakness of cytology in the diagnosis or prognosis of low-grade UC. A complementary approach should also include cellular-based markers, rather than soluble markers, to allow for a direct comparison of such biomarkers with morphological characteristics of urothelial cells.

\section{Conclusions}

UC is a challenging disease in terms of its diagnosis and surveillance. Urinary biomarkers have the potential to improve current diagnostic strategies, but they do not have sufficient sensitivity to safely replace cystoscopy in this setting. Future studies should focus on the identification and validation of biomarkers for early detection, particularly for low-grade and low-stage NMIBC. Diverse and rapidly evolving single-cell technologies provide remarkable opportunities for cancer biomarker discovery, and it is possible that in the next few years, a generation of new biomarkers using molecular personalized medicine approaches will enter the clinical setting. Moving forward, the development of highly sensitive and specific urinary assays coupled with single-cell technologies might revolutionize UC diagnosis, allowing for improved, early detection of the disease, ultimately improving UC treatment.

Author Contributions: Conceptualization and design, T.S.L. and J.Y.; literature review, M.H., G.H., S.G.; writing-original draft, M.H., G.H., S.G.; clinical input, A.W.X.L., K.J.T., T.K.H.L., L.Y.K.; intellectual input and critical review, J.Y., L.Y.K., T.S.L.; writing-review and final editing, M.H. All authors have read and agreed to the published version of the manuscript.

Funding: This research received no external funding.

Institutional Review Board Statement: Not applicable.

Informed Consent Statement: Not applicable.

Data Availability Statement: No new data were created or analyzed in this study. Data sharing is not applicable to this article.

Acknowledgments: The authors thank Insight Editing London for editing the manuscript prior to submission.

Conflicts of Interest: M.H. and T.S.L. are full-time employees of A. Menarini Biomarkers Singapore Pte Ltd. The rest of the authors declare no conflict of interest.

\section{References}

1. Richters, A.; Aben, K.K.H.; Kiemeney, L.A. The global burden of urinary bladder cancer: An update. World J. Urol. 2020, 38, 1895-1904. [CrossRef]

2. Bray, F.; Ferlay, J.; Soerjomataram, I.; Siegel, R.L.; Torre, L.A.; Jemal, A. Global cancer statistics 2018: GLOBOCAN estimates of incidence and mortality worldwide for 36 cancers in 185 countries. CA A Cancer J. Clin. 2018, 68, 394-424. [CrossRef] [PubMed]

3. Ferlay, J. Global Cancer Observatory: Cancer Today. Available online: http://gco.iarc.fr/today (accessed on 1 August 2020). 
4. Lee, C.S.; Yoon, C.Y.; Witjes, J.A. The past, present and future of cystoscopy: The fusion of cystoscopy and novel imaging technology. BJU Int. 2008, 102, 1228-1233. [CrossRef] [PubMed]

5. Risk, M.C.; Soubra, A. Diagnostics techniques in nonmuscle invasive bladder cancer. Indian J. Urol. 2015, 31, 283-288. [CrossRef]

6. Chakraborty, A.; Dasari, S.; Long, W.; Mohan, C. Urine protein biomarkers for the detection, surveillance, and treatment response prediction of bladder cancer. Am. J. Cancer Res. 2019, 9, 1104-1117. [PubMed]

7. D'Costa, J.J.; Goldsmith, J.C.; Wilson, J.S.; Bryan, R.T.; Ward, D.G. A Systematic Review of the Diagnostic and Prognostic Value of Urinary Protein Biomarkers in Urothelial Bladder Cancer. Bl. Cancer 2016, 2, 301-317. [CrossRef] [PubMed]

8. Goodison, S.; Chang, M.; Dai, Y.; Urquidi, V.; Rosser, C.J. A Multi-Analyte Assay for the Non-Invasive Detection of Bladder Cancer. PLoS ONE 2012, 7, e47469. [CrossRef]

9. Guo, A.; Wang, X.; Shi, J.; Sun, C.; Wan, Z. Bladder tumour antigen (BTA stat) test compared to the urine cytology in the diagnosis of bladder cancer: A meta-analysis. Can. Urol. Assoc. J. 2014, 8, 347-352. [CrossRef]

10. Glas, A.S.; Roos, D.; Deutekom, M.; Zwinderman, A.H.; Bossuyt, P.M.; Kurth, K.H. Tumor Markers in the Diagnosis of Primary Bladder Cancer. A Systematic Review. J. Urol. 2003, 169, 1975-1982. [CrossRef]

11. Wang, Z.; Que, H.; Suo, C.; Han, Z.; Tao, J.; Huang, Z.; Ju, X.; Tan, R.; Gu, M. Evaluation of the NMP22 BladderChek test for detecting bladder cancer: A systematic review and meta-analysis. Oncotarget 2017, 8, 100648-100656. [CrossRef]

12. He, H.; Han, C.; Hao, L.; Zang, G. ImmunoCyt test compared to cytology in the diagnosis of bladder cancer: A meta-analysis. Oncol. Lett. 2016, 12, 83-88. [CrossRef] [PubMed]

13. Chou, R.; Gore, J.L.; Buckley, D.; Fu, R.; Gustafson, K.; Griffin, J.C.; Grusing, S.; Selph, S. Urinary Biomarkers for Diagnosis of Bladder Cancer: A Systematic Review and Meta-analysis. Ann. Intern. Med. 2015, 163, 922-931. [CrossRef] [PubMed]

14. Cai, Q.; Wu, Y.; Guo, Z.; Gong, R.; Tang, Y.; Yang, K.; Li, X.; Guo, X.; Niu, Y.; Zhao, Y. Urine BLCA-4 exerts potential role in detecting patients with bladder cancers: A pooled analysis of individual studies. Oncotarget 2015, 6, 37500-37510. [CrossRef] [PubMed]

15. Kelly, J.D.; Dudderidge, T.J.; Wollenschlaeger, A.; Okoturo, O.; Burling, K.; Tulloch, F.; Halsall, I.; Prevost, T.; Prevost, A.T.; Vasconcelos, J.C.; et al. Bladder Cancer Diagnosis and Identification of Clinically Significant Disease by Combined Urinary Detection of Mcm5 and Nuclear Matrix Protein 22. PLoS ONE 2012, 7, e40305. [CrossRef]

16. E Khalbuss, W.; Goodison, S. Immunohistochemical detection of hTERT in urothelial lesions: A potential adjunct to urine cytology. CytoJournal 2006, 3, 18. [CrossRef]

17. Allison, D.B.; Sharma, R.; Cowan, M.L.; Vandenbussche, C.J. Evaluation of Sienna Cancer Diagnostics hTERT Antibody on 500 Consecutive Urinary Tract Specimens. Acta Cytol. 2018, 62, 302-310. [CrossRef]

18. Zhang, X.; Marjani, S.L.; Hu, Z.; Weissman, S.M.; Pan, X.; Wu, S. Single-Cell Sequencing for Precise Cancer Research: Progress and Prospects. Cancer Res. 2016, 76, 1305-1312. [CrossRef]

19. Srivastava, R.; Arora, V.K.; Aggarwal, S.; Bhatia, A.; Singh, N.; Agrawal, V. Cytokeratin-20 immunocytochemistry in voided urine cytology and its comparison with nuclear matrix protein-22 and urine cytology in the detection of urothelial carcinoma. Diagn. Cytopathol. 2011, 40, 755-759. [CrossRef]

20. I Morsi, M.; I Youssef, A.; E E Hassouna, M.; El-Sedafi, A.S.; A Ghazal, A.; Zaher, E.R. Telomerase activity, cytokeratin 20 and cytokeratin 19 in urine cells of bladder cancer patients. J. Egypt. Natl. Cancer Inst. 2006, 18, 82-92.

21. Golijanin, D.; Shapiro, A.; Pode, D. Immunostaining of cytokeratin 20 in cells from voided urine for detection of bladder cancer. J. Urol. 2000, 164, 1922-1925. [CrossRef]

22. Mi, Y.; Zhao, Y.; Shi, F.; Zhang, M.; Wang, C.; Liu, X. Diagnostic accuracy of urine cytokeratin 20 for bladder cancer: A metaanalysis. Asia-Pac. J. Clin. Oncol. 2019, 15, e11-e19. [CrossRef] [PubMed]

23. O'Sullivan, P.; Sharples, K.; Dalphin, M.; Davidson, P.; Gilling, P.; Cambridge, L.; Harvey, J.; Toro, T.; Giles, N.; Luxmanan, C.; et al. A Multigene Urine Test for the Detection and Stratification of Bladder Cancer in Patients Presenting with Hematuria. J. Urol. 2012, 188, 741-747. [CrossRef] [PubMed]

24. Van Valenberg, F.J.P.; Hiar, A.M.; Wallace, E.; Bridge, J.A.; Mayne, D.J.; Beqaj, S.; Sexton, W.J.; Lotan, Y.; Weizer, A.Z.; Jansz, G.K.; et al. Prospective Validation of an mRNA-based Urine Test for Surveillance of Patients with Bladder Cancer. Eur. Urol. 2019, 75, 853-860. [CrossRef] [PubMed]

25. Shariat, S.F.; Casella, R.; Khoddami, S.M.; Hernandez, G.; Sulser, T.; Gasser, T.C.; Lerner, S.P. Urine Detection of Survivin is a Sensitive Marker for the Noninvasive Diagnosis of Bladder Cancer. J. Urol. 2004, 171, 626-630. [CrossRef]

26. Springer, S.U.; Chen, C.-H.; Pena, M.D.C.R.; Li, L.; Douville, C.; Wang, Y.; Cohen, J.D.; Taheri, D.; Silliman, N.; Schaefer, J.; et al. Non-invasive detection of urothelial cancer through the analysis of driver gene mutations and aneuploidy. eLife 2018, 7. [CrossRef]

27. Van Kessel, K.E.; Beukers, W.; Lurkin, I.; Der Made, A.Z.-V.; Van Der Keur, K.A.; Boormans, J.L.; Dyrskjøt, L.; Márquez, M.; Ørntoft, T.F.; Real, F.X.; et al. Validation of a DNA Methylation-Mutation Urine Assay to Select Patients with Hematuria for Cystoscopy. J. Urol. 2017, 197, 590-595. [CrossRef]

28. Beukers, W.; Van Der Keur, K.A.; Kandimalla, R.; Vergouwe, Y.; Steyerberg, E.W.; Boormans, J.L.; Jensen, J.B.; Lorente, J.A.; Real, F.X.; Segersten, U.; et al. FGFR3, TERT and OTX1 as a Urinary Biomarker Combination for Surveillance of Patients with Bladder Cancer in a Large Prospective Multicenter Study. J. Urol. 2017, 197, 1410-1418. [CrossRef]

29. Ecke, T.H.; Weiß, S.; Stephan, C.; Hallmann, S.; Barski, D.; Otto, T.; Gerullis, H. UBC ${ }^{\circledR}$ Rapid Test for detection of carcinoma in situ for bladder cancer. Tumor Biol. 2017, 39, 1010428317701624. [CrossRef] 
30. Huang, Y.-L.; Chen, J.; Yan, W.; Zang, D.; Qin, Q.; Deng, A. Diagnostic accuracy of cytokeratin-19 fragment (CYFRA 21-1) for bladder cancer: A systematic review and meta-analysis. Tumor Biol. 2015, 36, 3137-3145. [CrossRef]

31. Li, C.; Li, H.; Zhang, T.; Li, J.; Liu, L.; Chang, J. Discovery of Apo-A1 as a potential bladder cancer biomarker by urine proteomics and analysis. Biochem. Biophys. Res. Commun. 2014, 446, 1047-1052. [CrossRef]

32. Li, H.; Li, C.; Wu, H.; Zhang, T.; Wang, J.; Wang, S.; Chang, J. Identification of Apo-A1 as a biomarker for early diagnosis of bladder transitional cell carcinoma. Proteome Sci. 2011, 9, 21. [CrossRef] [PubMed]

33. Chen, Y.-T.; Chen, C.-L.; Chen, H.-W.; Chung, T.; Wu, C.-C.; Chen, C.-D.; Hsu, C.-W.; Chen, M.-C.; Tsui, K.-H.; Chang, P.-L.; et al. Discovery of Novel Bladder Cancer Biomarkers by Comparative Urine Proteomics Using iTRAQ Technology. J. Proteome Res. 2010, 9, 5803-5815. [CrossRef] [PubMed]

34. Abogunrin, F.; O'Kane, H.F.; Ruddock, M.W.; Stevenson, M.; Reid, C.N.; O'Sullivan, J.M.; Anderson, N.H.; O'Rourke, D.; Duggan, B.; Lamont, J.V.; et al. The impact of biomarkers in multivariate algorithms for bladder cancer diagnosis in patients with hematuria. Cancer 2011, 118, 2641-2650. [CrossRef] [PubMed]

35. Rosser, C.; Charles, J.; Dai, Y.; Miyake, M.; Zhang, G.; Goodison, S. Simultaneous multi-analyte urinary protein assay for bladder cancer detection. BMC Biotechnol. 2014, 14, 24. [CrossRef]

36. Sheryka, E.; Wheeler, M.A.; Hausladen, D.A.; Weiss, R.M. Urinary interleukin-8 levels are elevated in subjects with transitional cell carcinoma. Urol. 2003, 62, 162-166. [CrossRef]

37. Urquidi, V.; Chang, M.; Dai, Y.; Kim, J.; Wolfson, E.D.; Goodison, S.; Rosser, C.J. IL-8 as a urinary biomarker for the detection of bladder cancer. BMC Urol. 2012, 12, 12. [CrossRef]

38. Bian, W.; Xu, Z. Combined assay of CYFRA21-1, telomerase and vascular endothelial growth factor in the detection of bladder transitional cell carcinoma. Int. J. Urol. 2007, 14, 108-111. [CrossRef]

39. Chen, L.-M.; Chang, M.; Dai, Y.; Chai, K.; Karl, X.; Dyrskjot, L.; Sanchez-Carbayo, M.; Szarvas, T.; Zwarthoff, E.; Lokeshwar, V.; et al. External Validation of a Multiplex Urinary Protein Panel for the Detection of Bladder Cancer in a Multicenter Cohort. Cancer Epidemiol. Biomark. Prev. 2014, 23, 1804-1812. [CrossRef]

40. Sun, Y.; He, D.-L.; Ma, Q.; Wan, X.-Y.; Zhu, G.-D.; Li, L.; Luo, Y.; He, H.; Yang, L. Comparison of seven screening methods in the diagnosis of bladder cancer. Chin. Med. J. 2006, 119, 1763-1771. [CrossRef]

41. Urquidi, V.; Kim, J.; Chang, M.; Dai, Y.; Rosser, C.J.; Goodison, S. CCL18 in a Multiplex Urine-Based Assay for the Detection of Bladder Cancer. PLoS ONE 2012, 7, e37797. [CrossRef]

42. Liang, Z.; Zhang, Q.; Wang, C.; Shi, F.; Cao, H.; Yu, Y.; Zhang, M.; Liu, X. Hyaluronic acid/Hyaluronidase as biomarkers for bladder cancer: A diagnostic meta-analysis. Neoplasma 2017, 64, 901-908. [CrossRef] [PubMed]

43. Srivastava, A.K.; Singh, P.K.; Singh, D.; Dalela, D.; Rath, S.K.; Bhatt, M. Clinical utility of urinary soluble Fas in screening for bladder cancer. Asia-Pac. J. Clin. Oncol. 2014, 12, e215-e221. [CrossRef] [PubMed]

44. Lu, Q.; Cheng, Y.; Deng, X.; Yang, X.; Li, P.; Wang, Z.; Li, P.; Tao, J.; Zhang, X. Urine microRNAs as biomarkers for bladder cancer: A diagnostic meta-analysis. OncoTargets Ther. 2015, 8, 2089-2096. [CrossRef] [PubMed]

45. Shi, H.-B.; Yu, J.-X.; Yu, J.-X.; Feng, Z.; Zhang, C.; Li, G.-Y.; Zhao, R.-N.; Yang, X.-B. Diagnostic significance of microRNAs as novel biomarkers for bladder cancer: A meta-analysis of ten articles. World J. Surg. Oncol. 2017, 15, 1-10. [CrossRef] [PubMed]

46. Eissa, S.; Zohny, S.F.; Swellam, M.; Mahmoud, M.H.; El-Zayat, T.M.; Salem, A.M. Comparison of CD44 and cytokeratin 20 mRNA in voided urine samples as diagnostic tools for bladder cancer. Clin. Biochem. 2008, 41, 1335-1341. [CrossRef]

47. Woodman, A.C.; Goodison, S.; Drake, M.; Noble, J.; Tarin, D. Noninvasive diagnosis of bladder carcinoma by enzyme-linked immunosorbent assay detection of CD44 isoforms in exfoliated urothelia. Clin. Cancer Res. 2000, 6, 2381-2392.

48. Smith, Z.L.; Guzzo, T.J. Urinary markers for bladder cancer. F1000Prime Rep. 2013, 5, 21. [CrossRef]

49. Yafi, F.A.; Brimo, F.; Steinberg, J.; Aprikian, A.G.; Tanguay, S.; Kassouf, W. Prospective analysis of sensitivity and specificity of urinary cytology and other urinary biomarkers for bladder cancer. Urol. Oncol. Semin. Orig. Investig. 2015, 33, 66.e25-66.e31. [CrossRef]

50. Chan, K.M.; Gleadle, J.M.; Li, J.Y.; Vasilev, K.; MacGregor, M. Shedding Light on Bladder Cancer Diagnosis in Urine. Diagnostics 2020, 10, 383. [CrossRef]

51. Kinders, R.; Jones, T.; Root, R.; Bruce, C.; Murchison, H.; Corey, M.; Williams, L.; Enfield, D.; Hass, G.M. Complement factor H or a related protein is a marker for transitional cell cancer of the bladder. Clin. Cancer Res. 1998, 4, 2511-2520.

52. Konety, B.R. Molecular markers in bladder cancer: A critical appraisal. Urol. Oncol. Semin. Orig. Investig. 2006, $24,326-337$. [CrossRef] [PubMed]

53. Gonzalgo, M.L.; Darwiche, F.; Parekh, D.J. Biomarkers for non-muscle invasive bladder cancer: Current tests and future promise. Indian J. Urol. 2015, 31, 273-282. [CrossRef] [PubMed]

54. Leiblich, A. Recent Developments in the Search for Urinary Biomarkers in Bladder Cancer. Curr. Urol. Rep. 2017, 18, 1-6. [CrossRef] [PubMed]

55. Greene, K.L.; Berry, A.; Konety, B.R. Diagnostic Utility of the ImmunoCyt/uCyt+ Test in Bladder Cancer. Rev. Urol. 2006, 8, 190-197.

56. Fradet, Y.; Lockhard, C. Performance characteristics of a new monoclonal antibody test for bladder cancer: ImmunoCyt trade mark. Can. J. Urol. 1997, 4, 400-405.

57. Toma, M.I.; Friedrich, R.E.; Hautmann, S.H.; Erbersdobler, A.; Hellstern, A.; Huland, H. Comparison of the ImmunoCyt test and urinary cytology with other urine tests in the detection and surveillance of bladder cancer. World J. Urol. 2004, 22, 145-149. [CrossRef] 
58. Kamat, A.M.; Hegarty, P.K.; Gee, J.R.; Clark, P.E.; Svatek, R.S.; Hegarty, N.; Shariat, S.F.; Xylinas, E.; Schmitz-Dräger, B.J.; Lotan, Y.; et al. ICUD-EAU International Consultation on Bladder Cancer 2012: Screening, Diagnosis, and Molecular Markers. Eur. Urol. 2013, 63, 4-15. [CrossRef]

59. Forsburg, S.L. Eukaryotic MCM Proteins: Beyond Replication Initiation. Microbiol. Mol. Biol. Rev. 2004, 68, 109-131. [CrossRef]

60. Williams, G.H.; Stoeber, K. Cell cycle markers in clinical oncology. Curr. Opin. Cell Biol. 2007, 19, 672-679. [CrossRef]

61. Stoeber, K.; Swinn, R.; Prevost, A.T.; De Clive-Lowe, P.; Halsall, I.; Dilworth, S.M.; Marr, J.; Turner, W.H.; Bullock, N.; Doble, A.; et al. Diagnosis of Genito-Urinary Tract Cancer by Detection of Minichromosome Maintenance 5 Protein in Urine Sediments. J. Natl. Cancer Inst. 2002, 94, 1071-1079. [CrossRef]

62. Zhang, Q.; Kim, N.-K.; Feigon, J. Architecture of human telomerase RNA. Proc. Natl. Acad. Sci. USA 2011, 108, $20325-20332$. [CrossRef] [PubMed]

63. Pantel, K.; Alix-Panabières, C.; Riethdorf, S. Cancer micrometastases. Nat. Rev. Clin. Oncol. 2009, 6, 339-351. [CrossRef] [PubMed]

64. Huang, X.; Gao, P.; Sun, J.; Chen, X.; Song, Y.; Zhao, J.; Xu, H.; Wang, Z.-N. Clinicopathological and prognostic significance of circulating tumor cells in patients with gastric cancer: A meta-analysis. Int. J. Cancer 2014, 136, 21-33. [CrossRef] [PubMed]

65. Lv, Q.; Gong, L.; Zhang, T.; Ye, J.; Chai, L.; Ni, C.; Ni, C. Prognostic value of circulating tumor cells in metastatic breast cancer: A systemic review and meta-analysis. Clin. Transl. Oncol. 2015, 18, 322-330. [CrossRef] [PubMed]

66. Rahbari, N.N.; Aigner, M.; Thorlund, K.; Mollberg, N.; Motschall, E.; Jensen, K.; Diener, M.K.; Büchler, M.W.; Koch, M.; Weitz, J. Meta-analysis Shows That Detection of Circulating Tumor Cells Indicates Poor Prognosis in Patients With Colorectal Cancer. Gastroenterology 2010, 138, 1714-1726.e13. [CrossRef]

67. Wang, S.; Zheng, G.; Cheng, B.; Chen, F.; Wang, Z.; Chen, Y.; Wang, Y.; Xiong, B. Circulating Tumor Cells (CTCs) Detected by RT-PCR and Its Prognostic Role in Gastric Cancer: A Meta-Analysis of Published Literature. PLoS ONE 2014, 9, e99259. [CrossRef]

68. Zhang, Z.; Fan, W.; Deng, Q.; Tang, S.; Wang, P.; Xu, P.; Wang, J.; Yu, M. The prognostic and diagnostic value of circulating tumor cells in bladder cancer and upper tract urothelial carcinoma: A meta-analysis of 30 published studies. Oncotarget 2017, 8, 59527-59538. [CrossRef]

69. Rink, M.; Schwarzenbach, H.; Vetterlein, M.W.; Riethdorf, S.; Soave, A. The current role of circulating biomarkers in non-muscle invasive bladder cancer. Transl. Androl. Urol. 2019, 8, 61-75. [CrossRef]

70. Bhatia, A.; Dey, P.; Kumar, Y.; Gautam, U.; Kakkar, N.; Srinivasan, R.; Nijhawan, R. Expression of cytokeratin 20 in urine cytology smears: A potential marker for the detection of urothelial carcinoma. Cytopathology. 2007, 18, 84-86. [CrossRef]

71. Lin, S.; Hirschowitz, S.L.; Williams, C.; Shintako, P.; Said, J.; Rao, J.Y. Cytokeratin 20 as an immunocytochemical marker for detection of urothelial carcinoma in atypical cytology: Preliminary retrospective study on archived urine slides. Cancer Detect. Prev. 2001, 25, 202-209.

72. Mai, K.T.; Teo, I.; Robertson, S.J.; Marginean, C.; Islam, S.; Yazdi, H.M. Immunostaining as a Diagnostic Aid in Cytopathologic Study of Upper Urinary Tract Urothelial Carcinoma. Acta Cytol. 2009, 53, 611-618. [CrossRef] [PubMed]

73. Bin Lim, S.; Lim, C.T.; Lim, W.T. Single-Cell Analysis of Circulating Tumor Cells: Why Heterogeneity Matters. Cancers 2019, 11, 1595. [CrossRef]

74. Akhtar, M.; Gallagher, L.; Rohan, S. Survivin: Role in Diagnosis, Prognosis, and Treatment of Bladder Cancer. Adv. Anat. Pathol. 2006, 13, 122-126. [CrossRef] [PubMed]

75. Shariat, S.F.; Ashfaq, R.; Karakiewicz, P.I.; Saeedi, O.; Sagalowsky, A.I.; Lotan, Y. Survivin expression is associated with bladder cancer presence, stage, progression, and mortality. Cancer 2007, 109, 1106-1113. [CrossRef]

76. Pena, M.D.C.R.; Springer, S.U.; Taheri, D.; Li, L.; Tregnago, A.C.; Eich, M.-L.; Eltoum, I.-E.A.; Vandenbussche, C.J.; Papadopoulos, N.; Kinzler, K.W.; et al. Performance of novel non-invasive urine assay UroSEEK in cohorts of equivocal urine cytology. Virchows Archiv 2020, 476, 423-429. [CrossRef]

77. Van Kessel, K.E.M.; Van Neste, L.; Lurkin, I.; Zwarthoff, E.C.; Van Criekinge, W. Evaluation of an Epigenetic Profile for the Detection of Bladder Cancer in Patients with Hematuria. J. Urol. 2016, 195, 601-607. [CrossRef]

78. Southgate, J.; Harnden, P.; Trejdosiewicz, L.K. Cytokeratin expression patterns in normal and malignant urothelium: A review of the biological and diagnostic implications. Histol. Histopathol. 1999, 14, 657-664.

79. Pichler, R.; Tulchiner, G.; Fritz, J.; Schaefer, G.; Horninger, W.; Heidegger, I. Urinary UBC Rapid and NMP22 Test for Bladder Cancer Surveillance in Comparison to Urinary Cytology: Results from a Prospective Single-Center Study. Int. J. Med Sci. 2017, 14, 811-819. [CrossRef]

80. Jeong, S.; Park, Y.; Cho, Y.; Kim, Y.R.; Kim, H.-S. Diagnostic values of urine CYFRA21-1, NMP22, UBC, and FDP for the detection of bladder cancer. Clin. Chim. Acta 2012, 414, 93-100. [CrossRef]

81. Chen, Y.-T.; Chen, H.-W.; Domański, D.; Smith, D.S.; Liang, K.-H.; Wu, C.-C.; Chen, C.-L.; Chung, T.; Chen, M.-C.; Chang, Y.-S.; et al . Multiplexed quantification of 63 proteins in human urine by multiple reaction monitoring-based mass spectrometry for discovery of potential bladder cancer biomarkers. J. Proteom. 2012, 75, 3529-3545. [CrossRef]

82. Koçak, H.; Oner-Iyidogan, Y.; Koçak, T.; Oner, P. Determination of diagnostic and prognostic values of urinary interleukin-8, tumor necrosis factor- $\alpha$, and leukocyte arylsulfatase-A activity in patients with bladder cancer. Clin. Biochem. 2004, 37, 673-678. [CrossRef] [PubMed]

83. Sağnak, A.L.; Ersoy, H.; Ozok, U.; Senturk, B.; Erçil, H.; Bahar, G.; Öztürk, E. Predictive Value of Urinary Interleukin-8 Cutoff Point for Recurrences After Transurethral Resection Plus Induction Bacillus Calmette-Guérin Treatment in Non-Muscle-Invasive Bladder Tumors. Clin. Genitourin. Cancer 2009, 7, E16-E23. [CrossRef] [PubMed] 
84. Campbell, S.C.; Volpert, O.V.; Ivanovich, M.; Bouck, N.P. Molecular mediators of angiogenesis in bladder cancer. Cancer Res. 1998, 58, 1298-1304. [PubMed]

85. Kumari, N.; Agrawal, U.; Mishra, A.K.; Kumar, A.; Vasudeva, P.; Mohanty, N.K.; Saxena, S. Predictive role of serum and urinary cytokines in invasion and recurrence of bladder cancer. Tumor Biol. 2017, 39. [CrossRef] [PubMed]

86. Morera, D.S.; Hennig, M.S.; Talukder, A.; Lokeshwar, S.D.; Wang, J.; Garcia-Roig, M.; Ortiz, N.; Yates, T.J.; E Lopez, L.; Kallifatidis, G.; et al. Hyaluronic acid family in bladder cancer: Potential prognostic biomarkers and therapeutic targets. Br. J. Cancer 2017, 117, 1507-1517. [CrossRef]

87. Hautmann, S.H.; Lokeshwar, V.B.; Schroeder, G.L.; Civantos, F.; Duncan, R.C.; Gnann, R.; Friedrich, M.G.; Soloway, M.S. Elevated Tissue Expression of Hyaluronic Acid and Hyaluronidase Validates the ha-Haase urine test for bladder cancer. J. Urol. 2001, 165, 2068-2074. [CrossRef]

88. Lokeshwar, V.B.; Obek, C.; Soloway, M.S.; Block, N.L. Tumor-associated hyaluronic acid: A new sensitive and specific urine marker for bladder cancer. Cancer Res. 1997, 57, 773-777.

89. Svatek, R.S.; Herman, M.P.; Lotan, Y.; Casella, R.; Hsieh, J.-T.; I Sagalowsky, A.; Shariat, S.F. Soluble Fas-A promising novel urinary marker for the detection of recurrent superficial bladder cancer. Cancer 2006, 106, 1701-1707. [CrossRef]

90. Desai, S.; Lim, S.D.; Jimenez, R.E.; Chun, T.; Keane, T.E.; McKenney, J.K.; Zavala-Pompa, A.; Cohen, C.; Young, R.H.; Amin, M.B. Relationship of Cytokeratin 20 and CD44 Protein Expression with WHO/ISUP Grade in pTa and pT1 Papillary Urothelial Neoplasia. Mod. Pathol. 2000, 13, 1315-1323. [CrossRef]

91. Yu, Q.; Stamenkovic, I. Localization of matrix metalloproteinase 9 to the cell surface provides a mechanism for CD44-mediated tumor invasion. Genes Dev. 1999, 13, 35-48. [CrossRef]

92. Liu, X.; Liu, X.; Wu, Y.; Wu, Q.; Wang, Q.; Yang, Z.; Li, L. MicroRNAs in biofluids are novel tools for bladder cancer screening. Oncotarget 2017, 8, 32370-32379. [CrossRef] [PubMed]

93. Pardini, B.; Cordero, F.; Naccarati, A.; Viberti, C.; Birolo, G.; Oderda, M.; Di Gaetano, C.; Arigoni, M.; Martina, F.; Calogero, R.A.; et al. microRNA profiles in urine by next-generation sequencing can stratify bladder cancer subtypes. Oncotarget 2018, 9, 20658-20669. [CrossRef] [PubMed]

94. Chen, L.; Cui, Z.; Liu, Y.; Bai, Y.; Lan, F. MicroRNAs as Biomarkers for the Diagnostics of Bladder Cancer: A Meta-Analysis. Clin. Lab. 2015, 59, 1101-1108. [CrossRef] [PubMed]

95. Kolodziejczyk, A.A.; Kim, J.K.; Svensson, V.; Marioni, J.C.; Teichmann, S.A. The Technology and Biology of Single-Cell RNA Sequencing. Mol. Cell 2015, 58, 610-620. [CrossRef] [PubMed]

96. Winterhoff, B.J.; Maile, M.; Mitra, A.K.; Sebe, A.; Bazzaro, M.; Geller, M.A.; Abrahante, J.E.; Klein, M.; Hellweg, R.; Mullany, S.A.; et al. Single cell sequencing reveals heterogeneity within ovarian cancer epithelium and cancer associated stromal cells. Gynecol. Oncol. 2017, 144, 598-606. [CrossRef] [PubMed]

97. Cohen, S.J.; Punt, C.J.A.; Iannotti, N.; Saidman, B.H.; Sabbath, K.D.; Gabrail, N.Y.; Picus, J.; Morse, M.; Mitchell, E.; Miller, M.C.; et al. Relationship of Circulating Tumor Cells to Tumor Response, Progression-Free Survival, and Overall Survival in Patients With Metastatic Colorectal Cancer. J. Clin. Oncol. 2008, 26, 3213-3221. [CrossRef]

98. Cristofanilli, M.; Budd, G.T.; Ellis, M.J.; Stopeck, A.; Matera, J.; Miller, M.C.; Reuben, J.M.; Doyle, G.V.; Allard, W.J.; Terstappen, L.W.; et al. Circulating Tumor Cells, Disease Progression, and Survival in Metastatic Breast Cancer. N. Engl. J. Med. 2004, 351, 781-791. [CrossRef]

99. De Bono, J.S.; Scher, H.I.; Montgomery, R.B.; Parker, C.; Miller, M.C.; Tissing, H.; Doyle, G.; Terstappen, L.W.; Pienta, K.J.; Raghavan, D. Circulating Tumor Cells Predict Survival Benefit from Treatment in Metastatic Castration-Resistant Prostate Cancer. Clin. Cancer Res. 2008, 14, 6302-6309. [CrossRef]

100. Riethdorf, S.; Fritsche, H.; Müller, V.; Rau, T.; Schindlbeck, C.; Rack, B.; Janni, W.; Coith, C.; Beck, K.; Jänicke, F.; et al. Detection of Circulating Tumor Cells in Peripheral Blood of Patients with Metastatic Breast Cancer: A Validation Study of the CellSearch System. Clin. Cancer Res. 2007, 13, 920-928. [CrossRef]

101. Riethdorf, S.; Soave, A.; Rink, M. The current status and clinical value of circulating tumor cells and circulating cell-free tumor DNA in bladder cancer. Transl. Androl. Urol. 2017, 6, 1090-1110. [CrossRef]

102. Chen, A.; Fu, G.; Xu, Z.; Sun, Y.; Chen, X.; Cheng, K.S.; Neoh, K.H.; Tang, Z.; Chen, S.; Liu, M.; et al. Detection of Urothelial Bladder Carcinoma via Microfluidic Immunoassay and Single-Cell DNA Copy-Number Alteration Analysis of Captured UrinaryExfoliated Tumor Cells. Cancer Res. 2018, 78, 4073-4085. [CrossRef] [PubMed]

103. Liang, L.-G.; Kong, M.-Q.; Zhou, S.; Sheng, Y.-F.; Wang, P.; Yu, T.; Inci, F.; Kuo, W.P.; Li, L.-J.; Demirci, U.; et al. An integrated double-filtration microfluidic device for isolation, enrichment and quantification of urinary extracellular vesicles for detection of bladder cancer. Sci. Rep. 2017, 7, srep46224. [CrossRef] [PubMed]

104. Lv, S.; Yu, J.; Zhao, Y.; Li, H.; Zheng, F.; Liu, N.; Li, D.; Sun, X. A Microfluidic Detection System for Bladder Cancer Tumor Cells. Micromachines 2019, 10, 871. [CrossRef] [PubMed]

105. Eissa, S.; Habib, H.; Ali, E.; Kotb, Y. Evaluation of urinary miRNA-96 as a potential biomarker for bladder cancer diagnosis. Med. Oncol. 2014, 32, 1-7. [CrossRef] [PubMed]

106. Mengual, L.; Lozano, J.J.; Ingelmo-Torres, M.; Gazquez, C.; Ribal, M.J.; Alcaraz, A. Using microRNA profiling in urine samples to develop a non-invasive test for bladder cancer. Int. J. Cancer 2013, 133, 2631-2641. [CrossRef]

107. Urquidi, V.; Netherton, M.; Gomes-Giacoia, E.; Serie, D.J.; Eckel-Passow, J.; Rosser, C.J.; Goodison, S. A microRNA biomarker panel for the non-invasive detection of bladder cancer. Oncotarget 2016, 7, 86290-86299. [CrossRef] [PubMed] 
108. Zhang, D.-Z.; Lau, K.-M.; Chan, E.S.Y.; Wang, G.; Szeto, C.-C.; Wong, K.; Choy, R.K.W.; Ng, C.-F. Cell-Free Urinary MicroRNA99a and MicroRNA-125b Are Diagnostic Markers for the Non-Invasive Screening of Bladder Cancer. PLoS ONE 2014, 9, e100793. [CrossRef]

109. Feber, A.; Dhami, P.; Dong, L.; De Winter, P.; Tan, W.S.; Martínez-Fernández, M.; Paul, D.S.; Hynes-Allen, A.; Rezaee, S.; Gurung, P.; et al. UroMark-a urinary biomarker assay for the detection of bladder cancer. Clin. Epigenetics 2017, 9, 8. [CrossRef]

110. Su, S.-F.; Abreu, A.L.D.C.; Chihara, Y.; Tsai, Y.; Andreu-Vieyra, C.; Daneshmand, S.; Skinner, E.C.; Jones, P.A.; Siegmund, K.; Liang, G. A Panel of Three Markers Hyper- and Hypomethylated in Urine Sediments Accurately Predicts Bladder Cancer Recurrence. Clin. Cancer Res. 2014, 20, 1978-1989. [CrossRef]

111. Wang, Y.; Yu, Y.; Ye, R.; Zhang, D.; Li, Q.; An, D.; Fang, L.; Lin, Y.; Hou, Y.; Xu, A.; et al. An epigenetic biomarker combination of PCDH17 and POU4F2 detects bladder cancer accurately by methylation analyses of urine sediment DNA in Han Chinese. Oncotarget 2016, 7, 2754-2764. [CrossRef] 